Teologia i Moralność, volumen 12(2017), numer 2(22)

doi: 10.14746/tim.2017.22.2.11

JOANNA BANASIUK

Uniwersytet w Białymstoku

Wydział Prawa

\title{
ALEKSANDER STĘPKOWSKI
}

Uniwersytet Warszawski

Wydział Prawa i Administracji

\section{Obywatelski projekt „Stop Aborcji” - prawne i doktrynalne uzasadnienie inicjatywy oraz ocena jej przebiegu}

Jednym z istotniejszych zagadnień będących zarówno przedmiotem rozważań na płaszczyźnie tworzenia i stosowania prawa, jak i w dyskursie publicznym, jest problematyka prawnej ochrony życia ludzkiego na prenatalnym etapie jego rozwoju. W ostatnim czasie szeroka dyskusja na ten temat pojawiła się przy okazji obywatelskiego projektu „Stop Aborcji”, będącego przedmiotem debaty sejmowej jesienią 2016 roku. Pomimo upływu ponad roku od trzeciego głosowania w niższej izbie parlamentu rozwiązania prawne projektu „Stop Aborcji” są nadal przedmiotem licznych komentarzy ze strony środowisk prawniczych, politycznych i medialnych. Uzasadnia to podjęcie próby usystematyzowania rozważań w zakresie prawnego i doktrynalnego ratio legis inicjatywy, także w kontekście Magisterium Kościoła katolickiego.

W pierwszej części artykułu zostaną przybliżone kulisy powstania projektu obywatelskiego oraz okoliczności jego odrzucenia. Następnie zostaną przeprowadzone rozważania na temat odpowiedzialności karnoprawnej matki z tytułu zabicia dziecka na prenatalnym etapie rozwoju. W dalszej kolejności przedstawione zostaną wyniki badań opinii publicznej przeprowadzonych $\mathrm{w}$ chwili uruchomienia projektu obywatelskiego a dotyczących prawnej ochrony życia. 


\section{Powstanie obywatelskiego projektu „Stop Aborcji” oraz okoliczności jego odrzucenia}

Projekt „Stop Aborcji” powstał w wyniku kilkumiesięcznych konsultacji koordynowanych przez Krajowy Ośrodek Duszpasterstwa Rodzin (dalej KODR), do udziału w których zaproszono wszystkie organizacje i osoby zaangażowane w obronę życia w Polsce ${ }^{1}$. Rozesłana 19 lutego 2016 roku o godz. 10:28 przez biuro KODR korespondencja elektroniczna potwierdza, że projekt w brzmieniu przygotowanym przez Instytut na rzecz Kultury Prawnej Ordo Iuris, który był efektem tych prac, poparła zdecydowana większość uczestników konsultacji w KODR uznając go za optymalny i poprawny, tak pod względem legislacyjnym, jak i doktrynalnym. Projekt powtarzał najważniejsze rozwiązania ustawy o prawnej ochronie dziecka poczętego, przygotowanej przez ekspertów Komisji Episkopatu Polski ds. Rodzin w lutym 1989 roku, który przewidywał całkowity zakaz aborcji oraz karalność wszystkich jej sprawców. Projekt z 1989 roku zapoczątkował proces, który cztery lata później doprowadził do istotnego ograniczenia prawnej dopuszczalności aborcji w naszym kraju.

Po zaakceptowaniu treści projektu, 23 lutego 2016 roku odbyły się pierwsze konsultacje z przedstawicielami Prawa i Sprawiedliwości (przede wszystkim z marszałkiem Ryszardem Terleckim). Stronę obywatelską reprezentowali wówczas P. Wosicki, A. Zięba, M. Dzierżawski oraz J. Kwaśniewski. Według relacji J. Kwaśniewskiego, obrońcy życia usłyszeli wówczas od polityków żądanie odłożenia w czasie inicjatywy. Przedstawiciele strony obywatelskiej wyrazili taką gotowość, o ile uzyskaliby od strony rządowej zapewnienie o podjęciu w przyszłości działań zmierzających do objęcia ochroną prawną życia dzieci na prenatalnym etapie ich rozwoju oraz konkretny harmonogram takich prac. Jak wskazuje J. Kwaśniewski, politycy zakomunikowali gotowość do dalszych rozmów o takim harmonogramie podczas kolejnego spotkania 3 marca. Jednocześnie wyrazili przekonanie o możliwości uruchomienia programów finansujących ze środków publicznych działalność edukacyjną w zakresie pro-life. Dwa dni po tym spotkaniu, tj. 25 lutego 2016 roku, przed-

${ }^{1}$ Wśród zaproszonych przez KODR byli m.in. przedstawiciele: Human Life International (Ewa Kowalewska), Polskiej Federacji Ruchów Obrony Życia PFROŻ (Antoni Zięba, Paweł Wosicki, Lech Łuczyński), Fundacji Mama i Tata (Paweł Woliński), CitizenGo (Magdalena Kaliszuk), Stowarzyszenia Kultury Chrześcijańskiej im. ks. Piotra Skargi (Sławomir Olejniczak, Sławomir Skiba), Fundacji Życie (Michał Owczarski), Fundacji PRO - Prawo do życia (Kinga Prybyłło, Mariusz Dzierżawski), Centrum Wspierania Inicjatyw dla Życia i Rodziny (Paweł Kwaśniak, Łukasz Woźniak), Instytutu na rzecz Kultury Prawnej Ordo Iuris (Jerzy Kwaśniewski, Błażej Kmieciak), Fundacji Nazaret (Maria Bienkiewicz), do udziału zaproszono również uznane autorytety związane z obroną życia: prof. Bogdana Chazana, mec. Olgierda Pankiewicza, mec. Jana Łopuszańskiego, Halinę Nowinę-Konopczynę, Nikoletę Brodę, Kaję Godek, ks. Ryszarda Halwę. 
stawiciele Polskiej Federacji Ruchów Obrony Życia (dalej PFROŻ) nie stawili się na zaplanowane wcześniej posiedzenie zespołu konsultacyjnego KODR, przesyłając list, w którym inż. A. Zięba pierwszy raz zdystansował się od inicjatywy i zapowiedział przedstawienie konkurencyjnego projektu.

Dnia 3 marca 2016 roku marszałek R. Terlecki oczekiwał przedstawicieli Fundacji PRO i Instytutu Ordo Iuris w towarzystwie A. Zięby i P. Wosickiego. Jak wskazywał J. Kwaśniewski, strona obywatelska usłyszała tym razem żądanie rezygnacji z inicjatywy z jednoczesną stanowczą odmową przedstawienia jakiegokolwiek wiążącego dla PiS harmonogramu dochodzenia w okresie późniejszym do pełnej prawnej ochrony życia.

W ocenie J. Kwaśniewskiego, pomimo niechęci władz klubu PiS, konsultacje prowadzone z posłami tej partii pozwalały mieć nadzieję na większościowe poparcie dla prawnej ochrony życia w razie braku dyscypliny klubowej podczas głosowania nad projektem obywatelskim. Pierwsze czytanie ustawy pokazało, że prognozy te były całkowicie uzasadnione. Zwracano również uwagę na szansę, jaką jest podjęcie tej inicjatywy w okresie wolnym od kampanii wyborczych oraz na początku kadencji parlamentarnej. Pośpiech dyktowany był również znacznym wzrostem liczby aborcji w ostatnich latach. W tej sytuacji, pomimo wycofania się PFROŻ, podjęto decyzję o zgłoszeniu inicjatywy.

Już po rozpoczęciu zbiórki podpisów pod projektem „Stop Aborcji” opublikowany został komunikat z 372. zebrania $\mathrm{KEP}^{2}$, w którym podano, iż biskupi „oświadczają, że nie popierają karania kobiet, które dopuściły się aborcji”. Tak ujęte stanowisko Episkopatu było wielokrotnie przedstawiane przez środowiska skupione w PFROŻ jako jednoznaczne potępienie obywatelskiego projektu ustawy. Upowszechniano w ten sposób, za pośrednictwem części mediów katolickich oraz „Gazety Wyborczej”, opinię, jakoby biskupi domagali się utrzymania w prawie polskim całkowitego i bezwarunkowego wykluczenia odpowiedzialności karnej matki za dobrowolne i umyślne uśmiercenie dziecka przed porodem. Taka interpretacja oświadczenia Episkopatu zaskoczyła środowiska obywatelskie, trudno bowiem znaleźć dla niej oparcie w Magisterium Kościoła. Kampania informacyjna dotycząca projektu została zdominowana przez wypowiedzi przedstawicieli PFROŻ epatujące opinię publiczną stwierdzeniami o dążeniu do karania kobiet wieloletnim więzieniem ${ }^{3}$. Całkowicie pomijano przy tym informację, że pod względem prawa karnego projekt po prostu zrównywał sytuację dziecka nienarodzonego z sytuacją prawną noworodka, przewidując dodatkowo zawsze możliwość odstąpienia od ukarania matki. Niestety, wy-

${ }^{2}$ Komunikat z 372. Zebrania Plenarnego Konferencji Episkopatu Polski z dnia 14-16 kwietnia 2016 r. http://episkopat.pl/komunikat-z-372-zebrania-plenarnego-konferencji-episkopatu-polski/ [dostęp: 22.12.2017].

${ }^{3}$ Zob. przykładowo: Parlament i media stanowiq o życiu i śmierci $-z d r$ Antonim Zięba, wiceprzewodniczacym PFROŻ rozmawia Leszek Sosnowski, „Miesięcznik Kulturalny WPIS” 11/2016, s. 4. 
powiedzi osób związanych z PFROŻ uwiarygodniły późniejsze nieprawdziwe twierdzenia skrajnych środowisk proaborcyjnych, które zaatakowały projekt, gdy ten zyskał zdecydowane poparcie podczas pierwszego czytania w Sejmie.

W dniu 5 października 2016 roku rzecznik KEP ks. dr Paweł Rytel-Andrianik, po zakończeniu zebrania plenarnego KEP, przypomniał treść komunikatu z 374. posiedzenia KEP ${ }^{4}$. Katolicka Agencja Informacyjna nie wyeksponowała jednak w swojej depeszy poparcia biskupów dla całkowitej ochrony życia, lecz stwierdzenie, że „,biskupi nie popierają projektów, które przewidują karanie kobiet, które dopuściły się aborcji”. Ta wersja komunikatu została powielona przez wszystkie media. Tego samego dnia o godz. 17 sejmowa Komisja Sprawiedliwości i Praw Człowieka przyjęła wniosek o odrzucenie obywatelskiego projektu „Stop Aborcji”. Niektórzy politycy publicznie głosili wówczas, jakoby episkopat upoważnił ich do takiego głosowania ${ }^{5}$. Projekt ostatecznie odrzucono kolejnego dnia rano.

\section{Odpowiedzialność karna matki za umyślne i dobrowolne zabójstwo prenatalne}

Wbrew narzuconej przez niektórych działaczy pro-life nieprawdziwej narracji, dla projektu „Stop Aborcji” przepisy karne chroniące dziecko przed zamachami ze strony matki były zagadnieniem drugorzędnym. Nadawały one jednak niezbędną spoistość projektowi, którego istotą była pełna ochrona życia ludzkiego na prenatalnym etapie rozwoju i uczynienie $\mathrm{z}$ obowiązujących przesłanek pozwalających na zabicie dziecka podstawę obowiązkowej pomocy państwa rodzinom znajdującym się w trudnych sytuacjach życiowych. Niestety, z kwestii drugorzędnej uczyniono główny instrument ataku na projekt chroniący życie. Dlatego też wyjaśnieniu tego zagadnienia należy poświęcić osobno uwagę.

\subsection{Stanowisko Magisterium Kościoła}

W świetle encykliki Evangelium vitae ${ }^{6}$ aborcja jest zbrodnią, której żadna ludzka ustawa nie może uznać za dopuszczalną. Katolik ma moralny obowią-

\footnotetext{
${ }^{4}$ Komunikat z 374. Zebrania Plenarnego Konferencji Episkopatu Polski z dnia 4-5 października 2016 r. http://episkopat.pl/komunikat-z-374-zebrania-plenarnego-konferencji-episkopatu-polski/ pkt 4. [dostęp: 22.12.2017].

${ }^{5} \mathrm{https}$ ://epoznan.pl/news-news-70668-Krystyna_Pawlowicz_episkopat_upowaznil_nas_do_od rzucenia_projektu [dostęp: 22.12.2017].

${ }^{6}$ Jan Paweł II, Evangelium Vitae Ojca Świętego Jana Pawła II do biskupów, do kapłanów i diakonów, do zakonników i zakonnic, do katolików świeckich oraz Do wszystkich ludzi dobrej woli
} 
zek przeciwstawienia się prawu dopuszczającemu aborcję i nie może popierać w głosowaniu regulacji, których skutkiem jest prawna jej dopuszczalność.

Jako „bezpośrednie zabójstwo niewinnych istot”7 aborcja nie ogranicza się do relacji między Bogiem a grzesznikiem. Mając daleko idące, dramatyczne skutki społeczne, pozostaje zawsze czynem zewnętrznym domagającym się stosownej reakcji ze strony państwa. Jan Paweł II ubolewał, że „w świadomości zbiorowej aborcyjne zamachy na życie tracą stopniowo charakter «przestępstwa» i w paradoksalny sposób zyskują status «prawa», do tego stopnia, że żąda się uznania ich pełnej legalności przez państwo, a następnie wykonywania ich bezpłatnie przez pracowników służby zdrowia"8. Z taką właśnie sytuacją mamy niestety do czynienia obecnie na gruncie polskiego prawa ${ }^{9}$.

Dlatego, każdy katolik jest moralnie zobowiązany do poparcia ustawy całkowicie zakazującej dokonywania aborcji, tzn. przewidującej odpowiedzialność karną każdego, kto uczestniczy w pozbawieniu życia dziecka w drodze procedury aborcyjnej. Jak uczył Jan Paweł II w Evangelium vitae (pkt 57), konkretyzując nauczanie encykliki Veritatis splendor ${ }^{10}$, ,,wobec normy moralnej, która zabrania bezpośredniego zabójstwa niewinnej istoty ludzkiej, nie ma dla nikogo żadnych przywilejów ani wyjątków".

Chociaż więc ,aborcja często jest dla matki przeżyciem dramatycznym i bolesnym" "11, bo może być uwikłana w chęć ratowania innych ważnych dóbr, to Jan Paweł II podkreślał, że ,wszystkie te i tym podobne racje, jakkolwiek poważne i dramatyczne, nigdy nie mogą usprawiedliwić umyślnego pozbawienia życia niewinnej istoty ludzkiej”" ${ }^{2}$. Dlatego też Kongregacja Nauki Wiary podkreśla, że „,w przypadku przerywania ciąży sama rezygnacja z karania wydaje się przynajmniej oznaczać, że prawodawca nie uważa już przerywania ciąży za przestępstwo przeciw życiu ludzkiemu, gdyż zabójstwo zawsze spotyka się z karą""13. Stanowi to konsekwentny wniosek wynikający z nauczania

o wartości i nienaruszalności życia ludzkiego z dnia 25 marca 1995 r., „Acta Apostolicae Sedis” 87 (1995), pkt 57, s. 465-466.

${ }^{7}$ Tamże, pkt 72 .

${ }^{8}$ Tamże, pkt 11.

${ }^{9}$ Art. 4b ustawy o planowaniu rodziny i warunkach dopuszczalności przerywania ciąży: „Osobom objętym ubezpieczeniem społecznym ... przysługuje praw o do bezpłatnego przerwania ciąży [wyróżnienie - JB, AS] w publicznym zakładzie opieki zdrowotnej” - Ustawa z dnia 7 stycznia 1993 r. o planowaniu rodziny, ochronie płodu ludzkiego i warunkach dopuszczalności przerywania ciąży (Dz.U. 93.17.78 z późn. zm.).

${ }^{10}$ Jan Paweł II, Veritatis splendor, Do wszystkich biskupów Kościoła katolickiego o niektórych podstawowych problemach nauczania moralnego Kościoła, „Acta Apostolicae Sedis” 85 (1993), pkt 96, s. 1209.

${ }^{11}$ Jan Paweł II, Evangelium vitae, pkt 58.

12 Tamże.

${ }^{13}$ Declaratio de abortu procurato, 18 Novembris 1974, „Acta Apostolicae Sedis” 66 (1974), par. 20, ss. 730-747. 
Jana Pawła II, który z naciskiem podkreślał, że aborcja jest zawsze ,świadomym i bezpośrednim zabójstwem istoty ludzkiej w początkowym stadium jej życia" ${ }^{14}$. Dlatego zapewnienie możliwości pociągnięcia do odpowiedzialności karnej każdej osoby będącej świadomym i bezpośrednim sprawcą zabójstwa przeprowadzonego $\mathrm{w}$ drodze aborcji, nie wyłączając również matki, jest nie tylko na gruncie prawa, ale też w świetle katolickiego nauczania moralnego, czymś oczywistym.

Nie mieli co do tego wątpliwości polscy biskupi, gdy w 1952 roku, pod przewodnictwem Prymasa Tysiąclecia stanowczo pisali w swym liście pasterskim: „od państwa oczekujemy surowych kar dla tych wszystkich, którzy przyczyniają się do śmierci nienarodzonych"15. Stanowisko Kościoła powszechnego w tym względzie zawiera punkt 2273 Katechizmu Kościoła katolickiego ${ }^{16}$ przywołujący fragment Instrukcji Donum vitae: „Gdy państwo nie używa swej władzy w służbie praw każdego obywatela, a w szczególności tego, który jest najsłabszy, zagrożone są podstawy praworządności państwa [...] Wyrazem szacunku i opieki należnej dziecku, które ma się narodzić, począwszy od chwili jego poczęcia, powinny być odpowiednie sankcje karne za każde dobrowolne pogwałcenia jego praw". Stanowisko to przypomniane zostało w Wyjaśnieniu Kongregacji Doktryny Wiary o aborcji opublikowanym w 2009 roku $^{17}$.

Realizacja tych oczywistych zasad ogólnych ma miejsce w porządku prawnym około 150 państw świata, wliczając w to prawo karne Państwa Watykańskiego, które (niezależnie od ekskomuniki latae sententiae w porządku duchowym) przewiduje odpowiedzialność karną każdego umyślnego sprawcy aborcyjnego zabicia dziecka. Odpowiedzialność karna matki za ten czyn nie została zniesiona również $\mathrm{w}$ wielkich nowelizacjach prawa karnego, przeprowadzanych za pontyfikatów Benedykta XVI i Franciszka.

Autorzy projektu „Stop aborcji” przeprowadzili szeroko zakrojone badania porównawcze, które wykazały, że żaden ze 123 krajów chroniących życie w wyższym stopniu niż Polska nie wyłącza ustawowo odpowiedzialności matek za uśmiercenie dziecka w drodze aborcji. Co więcej, wykazano, że wiele spośród państw dopuszczających aborcję w znacznie szerszym zakresie niż Polska - w tym Niemcy, Wielka Brytania czy Włochy - przewiduje kary dla matek świadomie i dobrowolnie dokonujących aborcji z naruszeniem prawa. Chociaż ustawodawstwo większości innych państw traktuje matki na równi

${ }^{14}$ Jan Paweł II, Evangelium vitae, pkt 58.

${ }^{15}$ List przedrukowany w Nasz Dziennik, 7 października 2016, Nr 235 (5683) http://wp.na szdziennik.p1/2016-10-07/253583, list-pasterski-episkopatu-polski-z-1952-r-w-obronie-zycia-niena rodzonych-fragmenty.html [dostęp: 27.12.2017].

${ }^{16}$ Katechizm Kościoła katolickiego, Poznań 2009.

${ }^{17}$ Wyjaśnienie Kongregacji Doktryny Wiary o aborcji, „L'Osservatore Romano”, 11 lipca 2009 r. 
z innymi współsprawcami aborcji, autorzy obywatelskiego projektu „Stop Aborcji” przewidzieli nieograniczoną możliwość odstąpienia przez sąd od kary wobec matki, nie obwarowując tej decyzji żadnymi warunkami. Zgodnie z projektem, odstąpienie od wymierzenia kary mogło nastąpić w każdym przypadku, bez konieczności wykazywania szczególnych okoliczności.

\subsection{Obecnie obowiązujący w Polsce stan prawny}

W świetle art. 1 kodeksu karnego, brak zagrożenia karą za dokonanie określonego czynu wyklucza możliwość pociągnięcia zań do odpowiedzialności karnej. Dlatego też, wykluczenie przez prawo polskie możliwości wymierzenia matce kary za zabicie dziecka przed urodzeniem - które to rozwiązanie wprowadzono w 1956 r. PRL w oparciu o wzorce i na wyraźne polecenie sowieckie - całkowicie wyklucza ochronę dziecka przez zamachami ze strony matki. W świetle prawa polskiego aborcja jest zatem całkowicie legalna o ile jej dokonuje matka. Dziecka nie chroni ani zaawansowane stadium rozwoju ani idealny stan zdrowia. Bezkarność matki odnosi się nie tylko do trzech przypadków, gdy to lekarz może dokonać aborcji zgodnie z prawem, ale ma zastosowanie do każdego innego - w tym dobrowolnego i umyślnego - zamachu na dziecko w prenatalnej fazie jego rozwoju, aż do rozpoczęcia porodu. Wprowadzenie tego rozwiązania do prawa polskiego w 1956 roku miało na celu całkowite pozbawienie podmiotowości człowieka w prenatalnej fazie rozwoju i zastąpienie ochrony podmiotowej dziecka przez ochronę bezosobowego stanu ciąży.

Obowiązująca wciąż zasada ustawowo gwarantowanej bezkarności matki umyślnie doprowadzającej do aborcji jest istotą proaborcyjnej zasady pro choice. Ustawowy zakaz karania za aborcję matek oznacza, że życie dziecka zależy wyłącznie od wyboru, jakiego dokona matka. Dziecku nie przysługuje żadna ochrona prawna przed zamachami na jego życie ze strony matki.

Prokurator nie może wszcząć postępowania w przypadku najbardziej nawet brutalnej i bezwzględnej i umyślnej aborcji jeśli jest dokonana przez matkę (nawet tej dokonanej w 9. miesiącu ciąży, a przypadki takie są znane). Z tych względów, obok zagrożenia sankcją działań osób trzecich doprowadzających do aborcji, niezbędne jest również objęcie dziecka realną ochroną prawnokarną przed dobrowolnym i umyślnym spowodowaniem aborcji przez jego matkę. Nie można $\mathrm{w}$ tym kontekście pominąć doświadczeń położnych obserwujących matki zmuszane przez bliskich do aborcji argumentem „tobie wolno, bo nic ci nie grozi”".

Odnosząc się do obywatelskiego projektu Stop Aborcji należy podkreślić, że odpowiedzialność karna matki za umyślne zabicie dziecka przed porodem 
została skonstruowana $\mathrm{w}$ sposób ściśle odpowiadający odpowiedzialności matki za zabicie dziecka po urodzeniu, pod wpływem tzw. szoku poporodowego. Jedyna różnica polegała na tym tylko, że szok poporodowy jest okolicznością ograniczającą poczytalność, natomiast odpowiedzialność karna matki za aborcję została ograniczona wyłącznie do czynów umyślnych i w pełni dobrowolnych (matka wciąż nie mogła być pociągnięta do odpowiedzialności za nieumyślne spowodowanie aborcji). Kwestionowanie zasadności zaproponowanej regulacji podaje w wątpliwość zasadność ochrony dziecka przed zamachami ze strony matki również po urodzeniu a przynajmniej oznacza akceptację tezy, jakoby pozbawienie żucia dziecka dokonane przez matkę przed urodzeniem nie stanowiło zabójstwa, co stoi w jaskrawej sprzeczności z nauczaniem Evangelium vitae.

Nie wolno też zapominać, że zaproponowane rozwiązanie miało na celu głównie prewencję, a zatem odstraszenie od popełnienia czynu oraz argument broniący przed naciskami osób trzecich, nie zaś - jak głosiło wielu katolików krytykujących projekt - ,wsadzanie kobiet do więzienia”.

\subsection{Problem wymiaru kary dla matki dokonującej aborcji}

Jest rzeczą oczywistą, że często mamy do czynienia z sytuacjami szczególnymi, których może doświadczać matka dopuszczająca się aborcji. Dlatego też projekt „Stop Aborcji” w najdalej idący sposób upoważniał sąd do odstąpienia lub złagodzenia wymiaru kary matce. Propozycja ta szła znacznie dalej niż propozycja KEP z 1989 roku. Jednakże możliwość odstąpienia od wymierzenia kary jest czymś gatunkowo różnym od bezwzględnego wykluczenia odpowiedzialności karnej. O ile to pierwsze chroni dziecko, pozwalając na uwzględnienie szczególnej sytuacji matki, o tyle to ostatnie wyklucza ochronę prawną dziecka przed zamachami ze strony matki. Projekt przewidywał realizację postulatu „niekarania kobiety” winnej umyślnego pozbawienia życia swego dziecka w art. $152 \S 5$ kodeksu karnego, przez najszerzej zakreśloną możliwość nadzwyczajnego złagodzenia kary lub odstąpienia od jej wymierzenia. Nawet wobec tzw. zabójstwa z litości (art. 150 §2 k.k.), dla odstąpienia od wymierzenia kary wymagane jest zaistnienie „wyjątkowych wypadków”. Takiego warunku odstąpienia od kary projekt obywatelski nie przewidywał ${ }^{18}$.

${ }^{18}$ Por. szerzej T. Zych, J. Kwaśniewski, Pelna ochrona prawna dziecka poczętego - aspekt prawnokarny, http://www.ordoiuris.pl/ochrona-zycia/pelna-ochrona-prawna-dziecka-poczetego-aspekt-pra wnokarny [dostęp: 22.12.2017]. 


\section{Motywacje autorów inicjatywy}

Większość uczestników konsultacji prowadzonych w KODR podzielała opinię, że w trybie inicjatywy obywatelskiej organizacje pro-life nie mogą propagować rozwiązań zawierających jakiekolwiek pozytywne przyzwolenie na zabijanie dzieci przed porodem. Wszyscy świadomi byli, że nie wolno nigdy „uczestniczyć w kształtowaniu opinii publicznej przychylnej prawu”19 dopuszczającemu aborcję. Promocją takiego niedopuszczalnego rozwiązania byłoby również przedłożenie projektu gwarantującego bezkarność dobrowolnego i umyślnego zabicia dziecka poczętego przez jego matkę.

Oczywiste było również to, że $\mathrm{w}$ trakcie prac parlamentarnych projekt może ulec zmianie, zaś ,jeśli nie byłoby możliwe odrzucenie lub całkowite zniesienie ustawy o przerywaniu ciąży, parlamentarzysta, którego osobisty absolutny sprzeciw wobec przerywania ciąży byłby jasny i znany wszystkim, postąpiłby słusznie, udzielając swego poparcia propozycjom, których celem jest ograniczenie szkodliwości takiej ustawy"20.

\section{Badania opinii publicznej}

Sondaże nie mają znaczenia dla oceny konieczności zapewnienia ochrony życia ludzkiego od momentu poczęcia. Są jednak źródłem ważnych informacji dla osób podejmujących inicjatywy społeczne i inicjujących proces legislacyjny. Oba sondaże na temat możliwości karania matek za aborcyjne uśmiercenie dziecka, przeprowadzone na zamówienie Instytutu Ordo Iuris w pracowni IBRIS, wykazały znaczne poparcie dla tego postulatu, i to poparcie wyższe niż dotyczące likwidacji pozostałych wyjątków aborcyjnych. Jaskrawo kontrastuje to z niepopartymi żadnymi argumentami tezami środowiska PFROŻ, jakoby postulat ochrony dziecka przed zamachami ze strony matki miał budzić szczególnie duże kontrowersje.

W majowym sondażu IBRiS 50,7\% badanych zadeklarowało, że kobiety powinny ponosić odpowiedzialność karną za „celowe i świadome dokonanie aborcji lub poddanie się jej”. Za uniemożliwieniem pociągnięcia do odpowiedzialności karnej kobiet w tych sytuacjach opowiedziało się 41,3\% badanych. Zważywszy na poparcie dla postulatu całkowitego zakazu aborcji na poziomie 59\%, należy uznać, że przed oświadczeniem KEP z kwietnia 2016 roku oraz negatywną kampanią PFROŻ skierowaną przeciw projektowi „Stop Aborcji”, aż 5/6 przeciwników aborcji wspierało postulat zniesienia automatycznej

\footnotetext{
${ }^{19}$ Jan Paweł II, Evangelium vitae, pkt 73.

20 Tamże.
} 
bezkarności kobiet za dokonanie aborcji. Wyniki IBRIS dotyczące karalności współgrają z rezultatami sondażu przeprowadzonego przez ośrodek Ariadna dla „Dziennika Gazety Prawnej” w dniach 8-12 kwietnia 2016 roku $^{21}$.

$$
* * *
$$

Retoryka stosowana intensywnie przez niektóre środowiska, w przewrotny sposób mówiąca m.in. o „karaniu kobiet” lub „wsadzaniu kobiet do więzienia", została przejęta i zradykalizowana przez środowiska feministyczne i antyrządowe oraz sprzyjające im media, tworząc przekłamany obraz projektu obywatelskiego w społeczeństwie.

Jednocześnie, forsowane utrzymanie wprowadzonej przez komunistów w 1956 roku zasady wykluczającej ochronę dziecka poczętego przed umyślnymi zamachami ze strony matki spowodowało istotny zamęt $\mathrm{w}$ społeczeństwie. $\mathrm{W}$ wielu środowiskach powstało fałszywe przeświadczenie, jakoby prawna ochrona dziecka poczętego przed zamachami ze strony matki umyślnie dokonującej aborcji sprzeciwiała się moralności katolickiej. Przekazy te trafiły także do innych państw. Obecnie w Wielkiej Brytanii ${ }^{22}$ i w Belgii ${ }^{23}$ feministki postulują, wzorem rozwiązania polskiego (sic!), zniesienie karalności matek nielegalnie dokonujących aborcji.

\author{
CIVIC "STOP ABORTION" PROJECT - \\ LEGAL AND DOCTRINAL JUSTIFICATION \\ OF THE INITIATIVE AND EVALUATION OF ITS PROGRES
}

\title{
Summary
}

In the light of the Encyclical Evangelium Vitae (point 73), abortion is a crime no human law can accept. As the direct murder of innocent beings (Evangelium Vitae point 72), abortion is not limited to the relationship between God and the sinner. With far reaching, dramatic social effects, it is always an external act demanding a proper response from the state. John Paul II regretted that, in collective consciousness, the abortive assassinations of life lose the character of "crime" and paradoxically gain

${ }^{21} \mathrm{http} / / /$ wiadomosci.dziennik.pl/wydarzenia/artykuly/518582,kobiety-chca-karac-ojcow-za-do konanie-aborcji.html [dostęp: 22.12.2017].

$22 \mathrm{https} / / /$ www.theguardian.com/world/2016/oct/11/british-women-please-rally-to-support-dec riminalisation-of-abortion?CMP=share_btn_fb [dostęp: 22.12.2017].

$23 \mathrm{http}: / /$ genethique.org/fr/belgique-premices-dune-reflexion-pour-liberaliser-lavortement-662 95.html\#.V_9QKCSpxMt [dostęp: 22.12.2017]. 
the status of "law," to the extent that they are demanded to recognize their full legitimacy by the state and then perform them free of charge by health workforce (Evangelium Vitae point 11). Although abortion is often a dramatic and painful experience for the mother, as it may be entangled in the desire to save other important values, John Paul II emphasized that all these and similar arguments, however serious and dramatic, can never justify intentional deprivation of an innocent life. (Evangelium Vitae, point 58). Therefore, the Congregation for the Doctrine of the Faith emphasizes that in case of terminating a pregnancy, resignation from punishing seems to mean that the legislature no longer considers abortion a crime against human life, since murder is always punishable. The implementation of these obvious general principles takes place in the legal order of about 150 countries of the world, including the criminal law of the Vatican City State, which (regardless of the excommunication latae sententiae in spiritual order) provides for the criminal responsibility of every deliberate perpetrator of abortion killing a child. The criminal liability of the mother for this act has not been abolished also in the great penal law reforms carried out for the pontificates of Benedict XVI and Francis. Although the legislation of most other states treats mothers equally with other abortion accomplices, the authors of the "Stop Abortion" project have envisaged the full possibility of the court canceling the penalty against the mother, without any condition being imposed by the court, i.e. according to the project notimposing the penalty could take place in every case, without the need to demonstrate particular circumstances.

Słowa kluczowe: aborcja; ,stop aborcji”

Keywords: abortion; "stop abortion"

\section{BIBLIOGRAFIA}

Declaratio de abortu procurato, 18 Novembris 1974, AAS 66 (1974), ss. 730-747.

Jan Paweł II, Evangelium Vitae Ojca Świętego Jana Pawła II do biskupów, do kapłanów i diakonów, do zakonników i zakonnic, do katolików świeckich oraz do wszystkich ludzi dobrej woli o wartości i nienaruszalności życia ludzkiego z dnia 25 marca 1995 r., „Acta Apostolicae Sedis” 87 (1995), ss. 401-522.

Jan Paweł II, Veritatis splendor, do wszystkich biskupów Kościoła katolickiego o niektórych podstawowych problemach nauczania moralnego Kościoła, „Acta Apostolicae Sedis” 85 (1993), ss. $1134-1228$.

Katechizm Kościoła katolickiego, Poznań 2009.

Komunikat z 372. Zebrania Plenarnego Konferencji Episkopatu Polski z dnia 14-16 kwietnia 2016 r. http://episkopat.pl/komunikat-z-372-zebrania-plenarnego-konferencji-episkopatu-polski/ [dostęp: 22.12.2017].

Komunikat z 374. Zebrania Plenarnego Konferencji Episkopatu Polski z dnia 4-5 października 2016 r. http://episkopat.pl/komunikat-z-374-zebrania-plenarnego-konferencji-episkopatu-polski/ [dostęp: 22.12.2017].

„L'Osservatore Romano”, 11 lipca 2009 r. 
Zych T., Kwaśniewski J., Petna ochrona prawna dziecka poczętego - aspekt prawnokarny, http:// www.ordoiuris.pl/ochrona-zycia/pelna-ochrona-prawna-dziecka-poczetego-aspekt-prawnokar ny [dostęp: 23.12.2017].

JoANNA BANASIUK - doktor nauk prawnych, adiunkt na Wydziale Prawa Uniwersytetuw Białymstoku.j.banasiuk@uwb.edu.pl

Aleksander StęPKowski - profesor Wydziału Prawa i Administracji Uniwersytetu Warszawskiego, kierownik Katedry Socjologii Prawa. astepkowski@wpia. uw.edu.pl 